\title{
Assessment of Spatial - Temporal Variations in Freshwater Pollution by Means of Water Quality Index: A Case Study of Hasanağa Stream Basin (Edirne, Turkey)
}

\section{Cem Tokatlı'10}

Cite this article as: Tokatli, C. (2021). Assessment of spatial - temporal variations in freshwater pollution by means of water quality index: A case study of Hasanağa stream basin (Edirne, Turkey). Aquatic Sciences and Engineering, 36(2), 66-71.

ORCID IDs of the author:

C.T. 0000-0003-2080-7920

TTrakya University, Ipsala Vocational School, Department of Laboratory Technology, Edirne, Turkey

Submitted:

11.07.2020

Revision Requested:

30.10 .2020

Last Revision Received:

03.11.2020

Accepted:

04.11 .2020

Online Published:

27.01.2021

Correspondence:

Cem Tokatlı

E-mail:

tokatlicem@gmail.com

(C) Copyright 2021 The Author(s)

Available online at

https://dergipark.org.tr/ase

\begin{abstract}
In this research, spatial - temporal variations of water quality in the fluvial components of the Hasanağa Stream Basin were evaluated by using the Water Quality Index. Surface water samples were taken from seven stations selected on the basin in the winter seasons of 2019 and 2020. Eleven variables including dissolved oxygen, oxygen saturation, $\mathrm{pH}$, electrical conductivity, total dissolved solids, salinity, turbidity, nitrate, nitrite, phosphate and sulphate were measured in freshwater samples. The Water Quality Index (WOI) and Cluster Analysis (CA) were applied to the detected data in order to determine the differences among the spatial - temporal contamination levels and classify the investigated locations according to their similar water quality characteristics. According to the detected data, the water of the Hasanağa Stream Basin has 1. - 2. Class quality in 2019 and 2. - 3. in 2020, in general. According to the results of WQI, although it was determined that the water quality decreased significantly in 2020, the basin was found to be of "A Grade - Excellent" water quality $(<50)$ in both 2019 and 2020. According to the results of the CA, 3 statistical clusters were formed and they were named as "less polluted zone", "moderate polluted zone" and "more polluted zone".
\end{abstract}

Keywords: Hasanağa stream basin, water quality index, cluster analysis

\section{INTRODUCTION}

Contamination of freshwater resources is a significant environmental problem, because of the increasing world population, the developments of industry and no environmental awareness in society. It is known that one of the main points in the effective management of freshwater resources is the monitoring of the quality of aquatic environments (Arslan et al., 2011; Tokatlı et al., 2014; 2016; Köse et al., 2014; 2016).

Water quality assessment indices are known to be an effective tool in evaluating the quality of water ecosystems. The Water Quality Index (WOI) has achieved increasing significance in the management of freshwater resources and it is one of the most commonly used freshwater quality indices and it is calculated from the perspective of the suitability of water for human consumption (Tyagi et al., 2013; Akter et al., 2016; Sutadian et al., 2016; Mukatea et al., 2019; Ustaoğlu and Tepe, 2019; Varol, 2020; Tokatlı and Ustauğlu, 2020). Describing the suitability of freshwater resources for domestic use especially in terms of the WOl is one of the most convenient ways to describe the current qualities of water ecosystems. The WOl also enables the modifications of policies by various environmental agencies (Akoteyon et al., 2011; Tokatlı and Ustauoğu, 2020; Ustaoğlu and Aydın, 2020; Tokatlı, 2020a).

Multi-statistical methods have been used to evaluate and characterise freshwater resourc- 
es and they help in the interpretation of complex data matrices and for them to be better understood. Cluster Analysis (CA) is known as one of the most convenient multivariate statistical methods. It assembles the objects based on the similar characteristics they possess (Akın et al., 2011; Varol et al., 2012; Belkhiri and Narany, 2015; Köse et al., 2018; Atıcı et al., 2018; Çiçek et al., 2019; Tokatlı, 2020b).

The Meriç-Ergene River Basin is the main watershed of the Thrace Region of Turkey. The Hasanağa Stream Basin is located in the Edirne Province of Turkey and it is one of the sub-basins of the Tunca River that is one of the main parts of the Meriç-Ergene River Basin. As in many aquatic ecosystems, the Hasanağa Stream Basin is adversely affected by agricultural and domestic discharges. The aim of this study was to determine the spatial and temporal variations of the water quality in this significant watershed by using the WOl.

\section{MATERIALS AND METHODS}

\section{Sample collection}

In this study, surface water samples were collected from seven stations located on the Hasanağa Stream Basin (3 of them were on the Sinanköy Stream, 3 of them were on the Korucuköy Stream and 1 of them was on the Hasanağa Stream) in the winter seasons of 2019 and 2020. The coordinate information of the locations is given in Table 1 and a map of the study area and the seven selected stations of the basin are given in Figure 1.

\section{Physical - Chemical and Statistical Analysis}

Dissolved oxygen (DO), oxygen saturation (OS), $\mathrm{pH}$, electrical conductivity (EC), total dissolved solids (TDS) and salinity variables were determined by using a multi - parameter device (Hach Lange - HQ40D) in the field studies; the turbidity variable was determined by using a turbidimeter device (Hach Lange $21000)$ in the field studies; nitrate $\left(\mathrm{NO}_{3}\right)$, nitrite $\left(\mathrm{NO}_{2}\right)$, phosphate $\left(\mathrm{PO}_{4}\right)$ and sulphate $\left(\mathrm{SO}_{4}\right)$ variables were determined by using a colorimeter device (Hach Lange - DR890) and by using a spectrophotometer device (Hach Lange - DR3900) in the laboratory studies.

Cluster Analysis (CA) and Similarity - Distance Index (SDI) (in terms of Bray Curtis) were applied to the detected data in order to the define the spatial differences of contamination by using the "PAST" package statistical program.

Table 1. Coordinate information of stations.

\begin{tabular}{llcc}
\hline \multirow{2}{*}{ Station Code } & \multicolumn{2}{c}{ Coordinate } \\
\cline { 3 - 4 } & Name of Stream & North & East \\
\hline S1 & & 41.838 & 26.749 \\
S2 & Sinanköy Stream & 41.777 & 26.683 \\
S3 & & 41.719 & 26.636 \\
K1 & & 41.862 & 26.700 \\
K2 & Korucuköy Stream & 41.791 & 26.657 \\
K3 & & 41.725 & 26.631 \\
H & Hasanağa Stream & 41.732 & 26.569
\end{tabular}

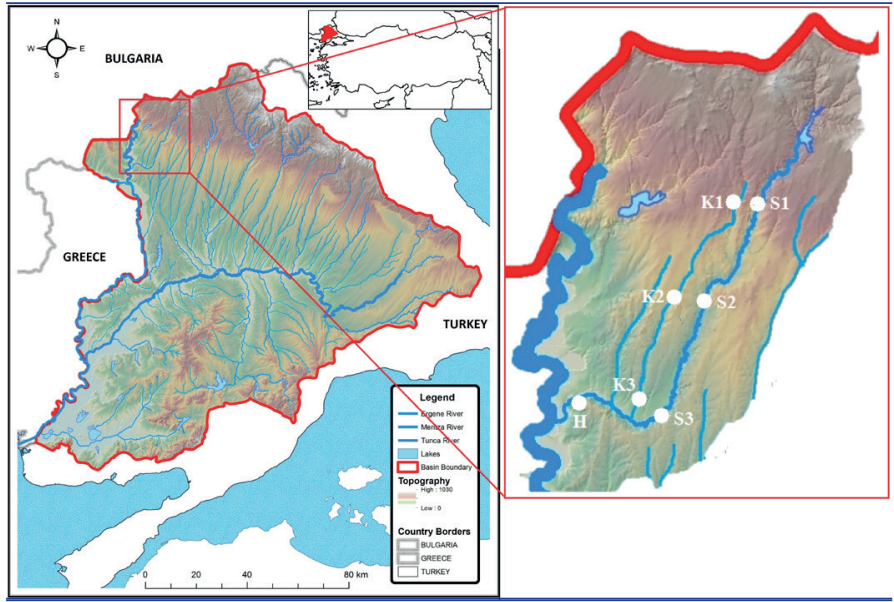

Figure 1. Meriç - Ergene River Basin, study area and selected stations.

\section{Water Quality Index (WOl)}

The WOl is an effective method in evaluating the drinking water quality and has commonly been used, especially in recent years (Wang et al., 2017; Tokatlı, 2019c; Ustaoğlu et al., 2020). The following formula was used to calculate the WOl;

$W Q I=\sum\left[W_{i} \times\left(\frac{C_{i}}{S_{i}}\right) \times 100\right]$

$W i=\frac{W_{i}}{\Sigma W_{i}}$

Where, $W_{i}$ is relative weight and $W_{i}$ values are assigned as a maximum of 5 and a minimum of 1 , taking into account the relatively significant effects of the toxicants on human health and their significance in terms of potability (Meng et al., 2016). $C_{i}$ is the trace-toxic element concentration measured in water and the $S$, values refer to the standard values determined by TS266 (2005), EC (2007) and WHO (2011) for drinking water. The Standard values (Si) of the investigated parameters with the assigned $\mathrm{Wi}$ coefficients in the present application are given in Table 2 (Meng et al., 2016). The scale of WOl is given in Table 3 (Xiao et al., 2019).

Table 2. Standard values, assigned weights and relative weights of parameters.

\begin{tabular}{lcccc} 
Variable & Unit & $\begin{array}{c}\text { Standart } \\
\text { Value }\left(\mathbf{S}_{\mathrm{i}}\right)\end{array}$ & $\begin{array}{c}\text { Assigned } \\
\text { Weight }\left(\mathbf{W}_{\mathrm{i}}\right)\end{array}$ & $\begin{array}{c}\text { Relative } \\
\text { Weight }\left(\mathbf{W}_{\mathbf{l}}\right)\end{array}$ \\
\hline $\mathrm{pH}$ & $\mathrm{WS}$ & 7.5 & 3 & 0.111111 \\
$\mathrm{EC}$ & $\mathrm{cm}$ & 1500 & 4 & 0.148148 \\
$\mathrm{TDS}$ & $\mathrm{mg} / \mathrm{L}$ & 600 & 4 & 0.148148 \\
Turbidity & $\mathrm{NTU}$ & 5 & 3 & 0.111111 \\
Nitrate & $\mathrm{mg} / \mathrm{L}$ & 50 & 5 & 0.185185 \\
Nitrite & $\mathrm{mg} / \mathrm{L}$ & 3 & 5 & 0.185185 \\
Sulphate & $\mathrm{mg} / \mathrm{L}$ & 250 & 3 & 0.111111
\end{tabular}


Table 3. Water quality rating for WQI

\begin{tabular}{lccc}
\hline Value & $\begin{array}{c}\text { Rating of Water } \\
\text { Quality }\end{array}$ & $\begin{array}{c}\text { Usage } \\
\text { Possibilities }\end{array}$ & Grading \\
\hline$<50$ & $\begin{array}{c}\text { Excellent water } \\
\text { quality } \\
\text { Good water } \\
\text { quality }\end{array}$ & $\begin{array}{c}\text { Drinking, irriga- } \\
\text { tion, industrial } \\
\text { Drinking, irriga- } \\
\text { tion, industrial } \\
\text { Irrigation, }\end{array}$ & $\mathrm{A}$ \\
100 & $\begin{array}{c}\text { Poor water } \\
\text { quality }\end{array}$ & B dustrial & $\mathrm{C}$ \\
200 & Very Poor water & Irrigation & D \\
$300-$ & quality & &
\end{tabular}

\section{RESULTS AND DISCUSSION}

The results of the detected limnological parameters in the main fluvial components of the Hasanağa Stream Basin in 2019 and 2020 are given in Table 3.

According to the Turkish Regulations (2004; 2015), In the winter season of 2019, the Hasanağa Stream Basin had a 1. Class quality in terms of dissolved oxygen, oxygen saturation, $\mathrm{pH}$, TDS and sulphate parameters and has a 2. Class quality in terms of the EC, nitrate, nitrite and phosphate parameters in general (Uslu and Türkman, 1987). In the winter season of 2020, the basin has a 1 . Class quality in terms of dissolved oxygen, oxygen saturation, TDS and sulphate parameters, and has a 2. Class quality in terms of the EC and nitrite parameters and has a 3. Class quality in terms of the $\mathrm{pH}$, nitrate and phosphate parameters in general (Uslu and Türkman, 1987). It was also determined that any investigated locations (except K3 station for turbidity parameter) did not exceed the drinking water standards in terms of the investigated parameters (TS266, 2005; EC, 2007; WHO, 2011).

Nitrate is caused by the oxidation of ammonia, which occurs as a result of the decomposition of proteins contained in animal and vegetable wastes, and especially nitrate fertilisers used in agricultural areas. A small amount of nitrate in clean waters is the most common form of nitrogen in streams (Wetzel, 2001; Manahan, 2011). Nitrite is an intermediate in biological oxidation from ammonium to nitrate, and it may have oxidised to nitrate or reduced to ammonia. It is mostly low in natural waters. Nitrite can reach high densities in low oxygenated waters with organic pollution and suggests sewage contamination if it is found in high amounts. The most important sources of nitrite in soils and waters are organic substances, nitrogenous fertilisers and some minerals (Wetzel, 2001; Manahan, 2011). Phosphorus is a significant essential element for plant growth. It is necessary for crop production and is commonly used in fertilisers. It is known as one of the main elements that increase the nutrient enrichment of surface waters and cause the ageing of lakes or streams (Wetzel, 2001; Manahan, 2011). The reason for the quite high nitrate, nitrite and phosphate values detected in the water of some basin components may have been the applied intensive agricultural fertilisers in the region.

CA was applied to the data in order to obtain the similarity groups among the investigated localities on the Hasanağa Stream Basin according to their similar water quality characteris- tics. The diagram of CA calculated by using the WOI scores of locations is given in Figure 2 and the calculated similarity coefficient of locations are given in Table 4.

According to the results of CA, 3 statistically significant clusters were formed. Cluster 1 (C1) was named as a "less contaminated zone" and corresponded to the stations $\mathrm{S} 1$ and $\mathrm{K} 1$; Cluster 2 (C2) was named as a "moderate contaminated zone" and corresponded to the station H, S2, S3 and K2; Cluster 3 (C3) was named as a "more contaminated zone" and corresponded to the station of K3.

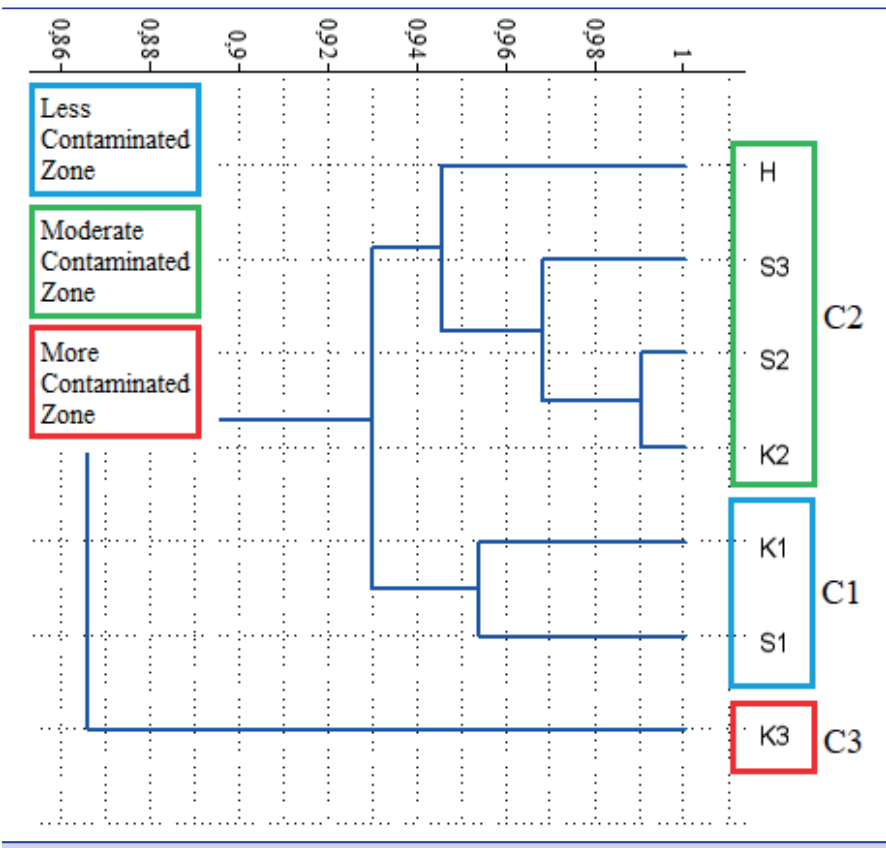

Figure 2. CA diagram.

Table 4. Similarity coefficients of locations.

\begin{tabular}{lccccccc}
\hline & S1 & S2 & S3 & K1 & K2 & K3 & H \\
\hline S1 & 1.000 & & & & & & \\
S2 & 0.942 & 1.000 & & & & & \\
S3 & 0.910 & 0.968 & 1.000 & & & & \\
K1 & 0.954 & 0.951 & 0.936 & 1.000 & & & \\
K2 & 0.942 & 0.990 & 0.968 & 0.941 & 1.000 & & \\
K3 & 0.806 & 0.862 & 0.894 & 0.851 & 0.862 & 1.000 & \\
H & 0.884 & 0.941 & 0.954 & 0.930 & 0.941 & 0.920 & 1.000
\end{tabular}

The Monomial and multinomial risks of $\mathrm{pH}, \mathrm{EC}$, TDS, turbidity, nitrate, nitrite and sulphate parameters in the water of the Hasanağa Stream Basin were determined for all the investigated habitats and seasons by using the WOI and the detected data are given in Table 4 and Figure 3.

According to the results of WOI, the values of the overall WOI were within the permissible limits $(<100)$, and all the investigated stations on the Hasanğa Stream Basin in all the seasons were found as "A grade - Excellent" in water quality characteristics. It was also determined that the risk sequence of the investigated parameters in the surface water of the basin is as follows; $\mathrm{pH}>$ TDS 
Table 3. Physical and chemical data detected in 2019 and 2020.

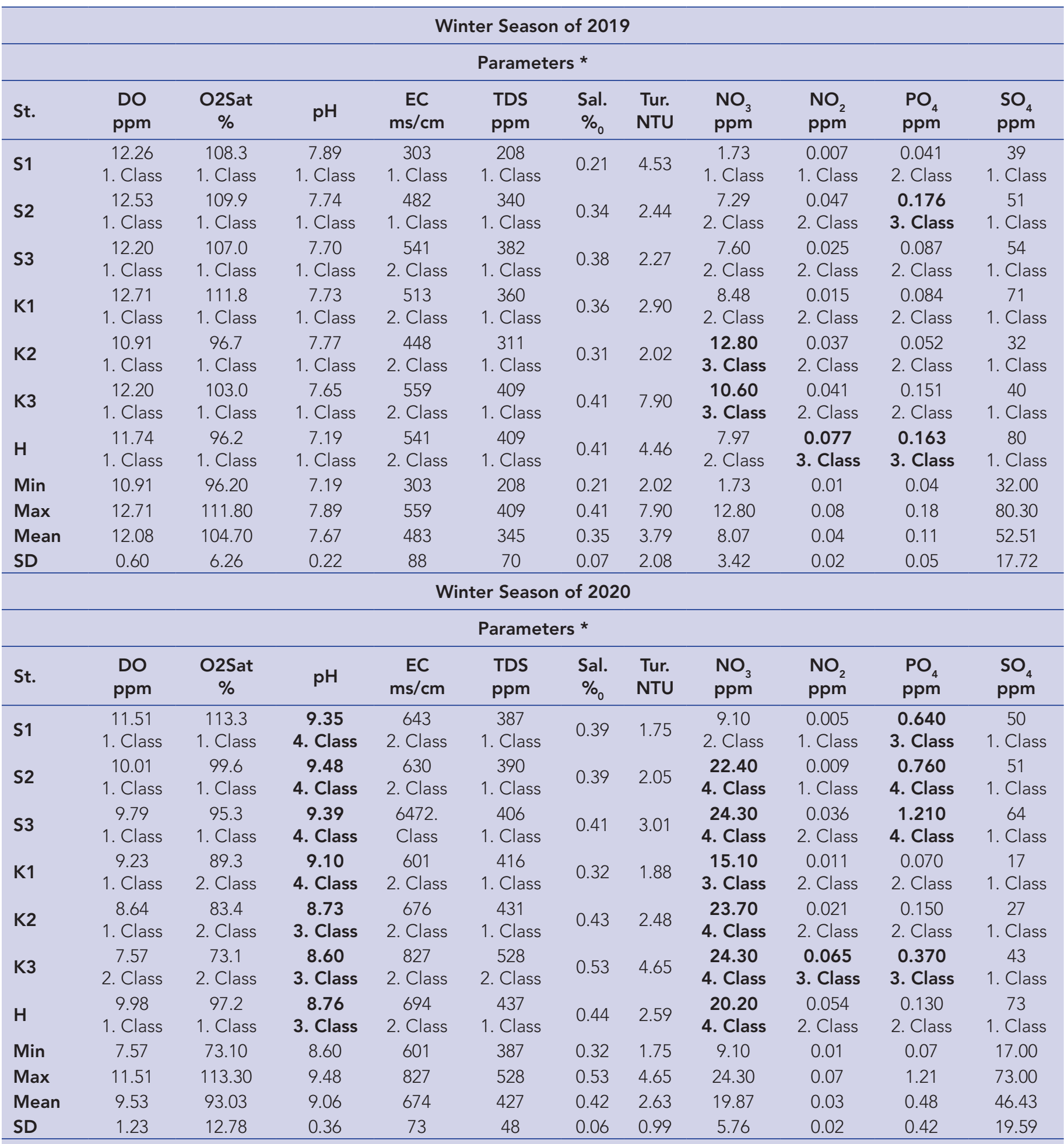

St.: Stations; Sal.: Salinity; Tur.: Turbidity; Min: Minimum; Max: Maximum; SD: Standard Deviation; *3. - 4. Class water qualities are given in bold

$>$ turbidity $>\mathrm{EC}>$ nitrate $>$ sulphate $>$ nitrite for 2019 and $\mathrm{pH}>$ TDS $>$ nitrate $>$ EC $>$ turbidity $>$ sulphate $>$ nitrite in general.

In a study performed in the catchments of the Emet and Orhaneli Streams, the water quality of the basin was evaluated by using the
WOI. According to the results of this investigation, being significantly different from the present investigation, the general trend of the WOI for Emet and Orhaneli Streams was found to be of a heavily polluted water quality (WOI > 300) (Omwene et al., 2019). 
Table 4. Monomial and multinomial results of applied WQI

\begin{tabular}{|c|c|c|c|c|c|c|c|}
\hline \multirow{2}{*}{ Parametre } & \multicolumn{3}{|c|}{$\begin{array}{l}\text { Sinanköy } \\
\text { Stream }\end{array}$} & \multicolumn{3}{|c|}{$\begin{array}{c}\text { Korucuköy } \\
\text { Stream }\end{array}$} & \multirow{2}{*}{$\begin{array}{c}\begin{array}{c}\text { Hasanağa } \\
\text { Stream }\end{array} \\
\text { H }\end{array}$} \\
\hline & S1 & S2 & S3 & $\mathrm{K} 1$ & K2 & K3 & \\
\hline \multicolumn{8}{|c|}{ Winter Season of 2019} \\
\hline $\mathrm{pH}$ & 11.689 & 11.467 & 11.407 & 11.452 & 11.511 & 11.333 & 10.652 \\
\hline EC & 2.993 & 4.760 & 5.343 & 5.067 & 4.425 & 5.521 & 5.343 \\
\hline Turbidity & 10.067 & 5.422 & 5.044 & 6.444 & 4.489 & 17.556 & 9.911 \\
\hline Nitrate & 0.641 & 2.700 & 2.815 & 3.141 & 4.741 & 3.926 & 2.952 \\
\hline Nitrite & 0.043 & 0.290 & 0.154 & 0.093 & 0.228 & 0.253 & 0.475 \\
\hline Sulphate & 1.742 & 2.244 & 2.400 & 3.173 & 1.422 & 1.787 & 3.569 \\
\hline WOl & 32.310 & 35.279 & 36.596 & 38.259 & 34.495 & 50.474 & 43.001 \\
\hline TDS & 9.556 & 9.630 & 10.025 & 10.272 & 10.642 & 13.037 & 10.790 \\
\hline Turbidity & 3.889 & 4.556 & 6.689 & 4.178 & 5.511 & 10.333 & 5.756 \\
\hline Nitrate & 3.370 & 8.296 & 9.000 & 5.593 & 8.778 & 9.000 & 7.481 \\
\hline Nitrite & 0.031 & 0.056 & 0.222 & 0.068 & 0.130 & 0.401 & 0.333 \\
\hline Sulphate & 2.222 & 2.267 & 2.844 & 0.756 & 1.200 & 1.911 & 3.244 \\
\hline wal & 39.270 & 45.070 & 49.081 & 40.283 & 45.870 & 55.591 & 47.437 \\
\hline
\end{tabular}

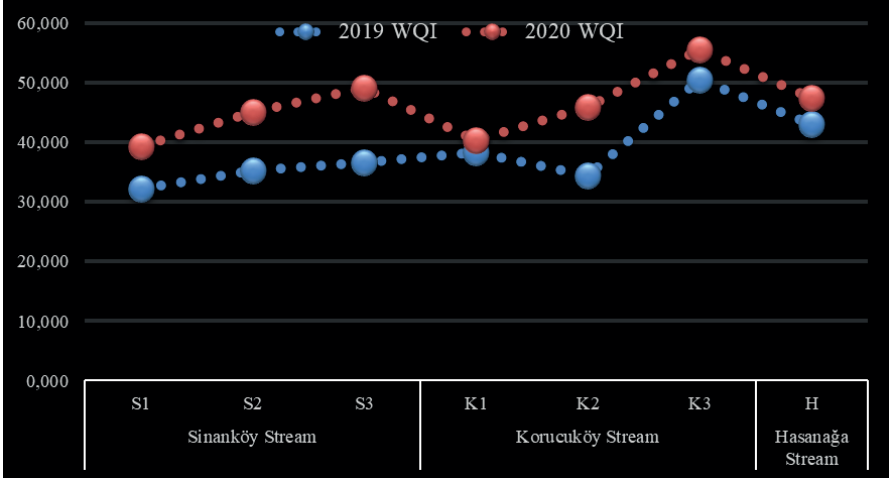

Figure 3. Spatial - temporal comparison of WOI scores.

In another study performed in the same watershed, the groundwater quality of the Ergene River Basin was evaluated by using the WOI. According to the results of this research, as similar to the present research, the investigated element accumulations in the groundwater of the basin were recorded within the range of human consumption standards (Tokatlı, 2019).

In a study performed in the Black See Region of Turkey, the WOI was used to assess the surface water qualities. As similar to the data of the current study, it was reported that the investigated Turnasuyu Stream has an excellent water quality in terms of the WOl (Ustaoğlu et al., 2020).

In a study conducted abroad in the city of Nagpur (India), The WOI was applied to determine the quality of different surface water resources. According to the results of this study, as differ- ent of the results of the present study, the calculated WOI for the various lakes studied showed poor water quality (Puri et al., 2011).

\section{CONCLUSION}

In the present research, the temporal and spatial change of the water quality of the Hasanağa Stream Basin including the Sinanköy, Korucuköy and Hasanağa Streams were evaluated by using the Water Quality Index (WOl) and Cluster Analysis (CA). As a result of this research, the water quality of the basin was found to have significantly decreased over time and it has a 1. - 2. Class water quality in 2019 and has a 2. - 3. Class water quality in 2020 in general. As a result of the WOl, the basin was found as having "A Grade - Excellent" water quality $(<50)$ in both 2019 and 2020. As a result of CA, 3 statistically significant clusters were formed and the locations investigated were classified as "less polluted zones", "moderate polluted zones" and "more polluted zones". For the protection and sustainability of this important aquatic system, it is necessary to constantly monitor and raise the awareness of local people in agricultural activities.

Financial Disclosure: The present study was funded by Trakya University, Commission of Scientific Research Projects (Project No. 2019/127)

Ethics committee approval: Ethics committee approval is not required.

Conflict of Interest: The authors have no conflicts of interest to declare. 


\section{Acknowledgments: -}

\section{Disclosure: -}

\section{REFERENCES}

Akin, B. S., Atıcı, T., Katircioglu, H., Keskin, F. (2011). Investigation of water quality on Gökçeekaya dam lake using multivariate statistical analysis, in Eskişehir, Turkey. Environmental Earth Sciences, 63: 1251-1261. [CrossRef]

Akoteyon, I. S., Omotayo, A. O., Soladoye, O., Olaoye, H. O. (2011). Determination of water quality index and suitability of urban river for municipal water supply in lagos-Nigeria. European Journal of Scientific Research, 54: 263-271.

Akter, T., Jhohura, F. T., Akter, F., Chowdhury, T. R., Mistry, S. K., Dey, D., Barua, M. K., Islam, M. A. \& Rahman, M. (2016). Water quality index for measuring drinking water quality in rural Bangladesh: A cross-sectional study. Journal of Health, Population and Nutrition, 35:4. [CrossRef]

Arslan, N., Tokatlı, C., Çiçek, A., Köse, E. (2011). Determination of some metal concentrations in water and sediment samples in Yedigöller region (Kütahya). Review of Hydrobiology 4,1: 17-28.

Atıcı, T., Tokatlı, C., Çiçek, A. (2018). Diatoms of Seydisuyu stream basin (Turkey) and assessment of water quality by statistical and biological approaches. Sigma Journal of Engineering and Natural Sciences, 36 (1): 271-288.

Belkhiri, L., Narany, T. S. (2015). Using multivariate statistical analysis, geostatistical techniques and structural equation modeling to identify spatial variability of groundwater quality. Water Resources Management, 29: 2073-2089. [CrossRef]

Çiçek, A., Köse, E., Tokatlı, C. (2019). Use of factor analysis to evaluate the sediment quality of a significant mining area: Seydisuyu stream basin (Turkey). Polish Journal of Environmental Studies, 28 (3): 2021-2025. [CrossRef]

EC (European Communities) (2007). European Communities (drinking water) (no. 2), Regulations 2007, S.I. No. 278 of 2007.

Köse, E., Çiçek, A., Uysal, K., Tokatlı, C., Emiroğlu, Ö. \& Arslan, N. (2016). Evaluation of surface water quality in Porsuk stream. University Journal of Science and Technology - C Life Sciences and Biotechnology, 4 (2): 81-93. [CrossRef]

Köse, E., Emiroğlu, Ö., Çiçek, A., Tokatlı, C., Başkurt, S., Aksu, S. (2018). Sediment quality assessment in porsuk stream basin (Turkey) from a multi-statistical perspective. Polish Journal of Environmental Studies, 27 (2): 747-752. [CrossRef]

Köse, E., Tokatlı, C. \& Çiçek, A. (2014). Monitoring stream water quality: A statistical evaluation. Polish Journal of Environmental Studies, 23 (5): 1637-1647

Manahan, S. E. (2011). Water Chemistry: Green Science and Technology of Nature's Most Renewable Resource. Taylor and Francis Group. CRC Press, 398p. [CrossRef]

Meng, Q., Zhang, J., Zhang, Z., Wu, T. (2016). Geochemistry of dissolved trace elements and heavy metals in the dan river drainage (China): Distribution, sources, and water quality assessment. Environmental Science and Pollution Research, 23, 8091-8103. [CrossRef]

Mukatea, S., Wagha, V., Panaskara, D., Jacobs, J. A. \& Sawantc, A. (2019). Development of new integrated water quality index (IWOI) model to evaluate the drinking suitability of water. Ecological Indicators, 101, 348-354. [CrossRef]

Puri, P. J., Yenkie, M. K. N., Sangal, S. P., Gandhare, N. V., Sarote, G. B. \& Dhanorkar, D. B. (2011). Surface water (lakes) quality assessment in nagpur city (India) based on water quality index (WOI). Rasayan Journal of Chemistry, 4(1): 43-48.

Sutadian, A. D., Muttil, N., Yilmaz, A. G., Perera, B. J. C. (2016). Development of river water quality indices-A review. Environmental Monitoring and Assessment, 188: 58. [CrossRef]

Tokatlı, C. (2019). Drinking Water Quality Assessment of Ergene River Basin (Turkey) by water quality index: Essential and toxic elements. Sains Malaysiana, 48 (10): 2071-2081. [CrossRef]
Tokatlı, C., 2020a. Use of water quality index to evaluate the groundwater characteristics of villages located in edirne province. International Journal of Agriculture, Environment and Food Sciences, 4(3): 362 367. [CrossRef]

Tokatlı, C., 2020b. Water quality assessment of Ergene river basin using multivariate statistical analysis. Journal of Limnology and Freshwater Fisheries Research, 6 (1): 38-46. [CrossRef]

Tokatlı, C., Köse, E., Arslan, N., Emiroğlu, Ö., Çiçek, A. \& Dayıoğlu, H. (2016). Water quality of emet stream basin. Uludağ University Journal of the Faculty of Engineering, 21(2): 9-24. [CrossRef]

Tokatlı, C., Köse, E. \& Çiçek, A. (2014). Assessment of the effects of large borate deposits on surface water quality by multi statistical approaches: A case study of the Seydisuyu stream (Turkey). Polish Journal of Environmental Studies, 23(5): 1741-1751.

Tokatlı, C., Ustaoğlu, F. (2020). Health risk assessment of toxicants in Meriç river delta wetland, thrace region, Turkey. Environmental Earth Science, 79, 426. [CrossRef]

TS 266 (2005). Sular-Insani tüketim amaçlı sular. Türk Standartları Enstitüsü, ICS 13.060.20

Turkish Regulations (2004). Yüzeysel Su Kalitesi Yönetimi Yönetmeliği, 31 Aralık 2004, Resmi Gazete No: 25687, http://suyonetimiormansu.gov.tr.

Turkish Regulations (2015). Yüzeysel su kalitesi yönetimi yönetmeliğinde değişiklik yapılmasına dair yönetmelik, 15 Nisan 2015, Resmi Gazete No: 29327, http://suyonetimiormansu.gov.tr.

Tyagi, S., Sharma, B., Singh, P. \& Dobhal, R. (2013). Water quality assessment in terms of water quality index. American Journal of Water Resources, 1(3):34-8. [CrossRef]

Uslu, O. \& Türkman, A. (1987). Su kirliliği ve kontrolü. T.C. Başbakanlık Çevre Genel Müdürlüğü Yayınları, Eğitim Dizisi 1, Ankara.

Ustaoğlu, F., Aydın, H. (2020). Health risk assessment of dissolved heavy metals in surface water in a subtropical rivers basin system of Giresun (north-eastern Turkey). Desalination and Water Treatment, 194, 222234. [CrossRef]

Ustaoğlu, F. \& Tepe, Y. (2019). Water quality and sediment contamination assessment of Pazarsuyu stream, Turkey using multivariate statistical methods and pollution indicators. International Soil and Water Conservation Research, 7, 47-56. [CrossRef]

Ustaoğlu, F., Tepe, Y. \& Taş, B. (2020). Assessment of Stream quality and health risk in a subtropical Turkey river system: A combined approach using statistical analysis and water quality index. Ecological Indicators, [CrossRef]

Varol, M. (2020). Use of water quality index and multivariate statistical methods for the evaluation of water quality of a stream affected by multiple stressors: a case study. Environmental Pollution, 266: 115417. [CrossRef]

Varol , M., Gökot B., Bekleyen, A., Şen, B. (2012). Water quality assessment and apportionment of pollution sources of Tigris river (Turkey) Using multivariate statistical techniques-a case study. River Research and Applications, 28, 1428-1438. [CrossRef]

Wang, J., Liu, G., Liu, H. \& Lamc, P. (2017). Multivariate statistical evaluation of dissolved trace elements and a water quality assessment in the middle reaches of Huaihe river, Anhui, China. Science of the Total Environment, 583: 421-431. [CrossRef]

Wetzel, R. G. (2001). Limnology: Lake and River Ecosystems. Elsevier Academic Press. 1006p. [20] Manahan, S.E. (2011) Water Chemistry: Green Science and Technology of Nature's Most Re-newable Resource. Taylor and Francis Group. CRC Press, 398p.

WHO (World Health Organization) (2011). Guidelines for Drinking-water Quality. World Health Organization Library Cataloguing-inPublication Data, NLM classification: WA 675.

Xiao, J., Wang, L., Deng, L. \& Jin, Z. (2019). Characteristics, sources, water quality and health risk assessment of trace elements in river water and well water in the Chinese loess plateau. Science of the Total Environment, 650: 2004-2012. [CrossRef] 